\title{
Regional public goods in North America
}

\author{
Book or Report Section
}

Published Version

Creative Commons: Attribution-Noncommercial-No Derivative Works 4.0

Open access

Long, T. and Suarez-Mier, M. (2017) Regional public goods in North America. In: Goodman, L. W. and Estevadeordal, A. (eds.) 21st Century Cooperation: Regional Public Goods, Global Governance and Sustainable Development. Routledge, New York, pp. 265-286. ISBN 9781138722590 Available at http://centaur.reading.ac.uk/66279/

It is advisable to refer to the publisher's version if you intend to cite from the work. See Guidance on citing.

Publisher: Routledge

All outputs in CentAUR are protected by Intellectual Property Rights law, including copyright law. Copyright and IPR is retained by the creators or other copyright holders. Terms and conditions for use of this material are defined in the End User Agreement. 


\section{CentAUR}

Central Archive at the University of Reading

Reading's research outputs online 


\title{
13 Regional public goods in North America
}

\author{
Tom Long and Manuel Suárez-Mier
}

\section{Introduction}

The North American Leaders Summit, held on June 292016 in Ottawa, brought together three telegenic heads of state: recently elected Prime Minister Justin Trudeau of Canada, President Enrique Peña Nieto of Mexico, and President Barack Obama of the United States of America (USA). The "three amigos" offered a positive picture of integration and cooperation on issues ranging from energy and the environment to trade and the Trans-Pacific Partnership. The pleasant photo op belied a complicated reality for North America, however. Cooperation had stagnated for years as Trudeau's predecessor declined to schedule a summit in retaliation for Obama's hesitation and ultimate rejection of a major oil pipeline. The US Congress and both major presidential candidates threatened to reject the TPP, while the Republican nominee promised to "break" the region's fundamental trade accord and build a wall on the USA-Mexico border. Mexico struggled with the implementation of once-touted reforms, while concerns over security and governance continued. The moment highlighted the need for and possibilities of trilateral cooperation, but also underlined the existential risks for North America's future as a region.

Until the previous 25 years, "North America" has rarely been considered a region, and until then, it encompassed only the USA and Canada. ${ }^{1}$ Only in the early 1990s, when Mexico sought a free trade agreement with the USA, did a tri-national region begin to emerge. For most of the three countries' histories, the shared continental geography was defined by the dominant presence of the USA and the potential or actual regional "bads" that emerged from it. During the 19th century, the USA threatened Canada's and Mexico's territorial integrity and independence - a threat made real when the USA annexed half of Mexico's territory in 1848 and followed with incursions into Mexico lasting into World War I. That threat dissipated in the following decades, but both Mexico and Canada adopted policies intended to keep their powerful neighbor at a distance by limiting investment, the presence of American companies, and the presence of US media. 
Despite those policies, geography helped propel the flow of trade and people among the three countries. The ultimate goal of regional public goods (RPGs) is understood as promoting peace and prosperity. In North America, peace - at least at the interstate level-took shape even as policies aimed at regional prosperity received limited and sporadic attention. Cooperation grew more quickly between the USA and Canada, with 92 bilateral treaties signed between 1948 and 1965, compared to 38 between the USA and Mexico. ${ }^{2}$ The year 1965 was an early watershed: the Canada-United States Automotive Products Agreement represented an early step in the production of RPGs aimed at enhancing regional prosperity. Regionalism took a quantum leap forward in 1988, with the negotiation of an FTA between the USA and Canada. Canada sought the agreement as a way to emerge from economic stagnation, and the agreement's model for RPGs relied heavily on an open US market. The agreement broke ground by including nontariff barriers, trade in services, and dispute resolution. RPG production centered on increased trade and investment; however, it indirectly deepened US-Canadian cooperation in a number of spheres. Clearer dispute resolution procedures helped produce greater rule of law at the bilateral level, which would become even more important in the ensuing trilateral accord.

The North American Free Trade Agreement (NAFTA) formally expanded the region to Mexico-catching up with economic and social trends-and enhanced the demand for and potential of RPGs. NAFTA was founded on the premise that important RPGs would be generated by the closer economic integration of the three countries. In particular, it was assumed that the virtual disappearance of trade barriers in North America would increase trade in a spectacular form — which it did — and that higher volumes of trade would result in faster rates of economic growth, particularly for Mexico, the smallest of the three economies. Unfortunately, this latter assumption did not hold true, since the average rate of growth of the Mexican economy has remained disappointingly low since NAFTA came into effect in 1994.

NAFTA represented a different approach to regionalism, though with similarities to the types that Amitav Acharya discusses in Chapter 3 of this volume. As a region defined by asymmetry and economically dependent on the huge US market, it has aspects of hegemonic regionalism. However, North America was brought into being by Canadian and Mexican initiatives, and the US government has rarely dedicated great attention to the region. In its economic aspects and its legalism, NAFTA represented an integrationist effort. However, it has not followed the European model of building regional bureaucracies, nor ASEAN's model of frequent consultation and engagement with external powers. There has been relatively limited spillover in the neofunctionalist sense of growing demands for cooperation and institutionalization across issue areas. Through NAFTA, the three countries took steps away from protectionism and nationalist policies, but at a governmental level have shown little initiative to go beyond that. Some of these relative gains have been reversed since 2001, after which stagnation has become the rule. North America has prized the 
national over the supranational, and in almost all cases, Canada, Mexico, and the USA engage with the rest of the world as individual states, not as a region. Despite these differences, we argue that North America should be treated as a region. Geography provides an obvious rationale; more important are the myriad connections among the three countries, which range from production chains to family networks. Using an RPG framework, we describe goods that have been created in the region and areas in which those goods are lacking.

With the important exceptions of trade and investment, many of the RPGs forecasted to be the major accomplishments of the new trading bloc did not materialize, particularly rapid and sustained economic growth in Mexico. Other RPGs that were not so obvious at the launching of NAFTA, like enhancing the rule of law in Mexico and at the regional level, with positive effects for foreign investment throughout the region, were more salient. While enhanced rule of law has benefited actors at the regional levels of the economies, NAFTA did not—and probably could not-create rule of law that would spill over to the economies as a whole. As such, important sectoral and geographic disparities in goods provision remain. As a recent McKinsey Global Institute study by Bolio et al. (2014) demonstrates, while productivity of the "modern" sector of the Mexican economy with close ties to NAFTA grew at a compounded annual rate of 5.8\% per year between 1999 and 2009, the productivity of the "traditional" firms that cater to the domestic market, including those in the informal economy, has fallen at an annual compounded rate of $6.5 \%$. RPGs only partially compensate for weak goods production at the national and local levels.

This paper will briefly examine the concept of RPGs as it applies to North America. Focusing on the role of these goods, it contextualizes today's situation with a succinct account of North American integration. The paper argues that rule of law has emerged as one of the most important RPGs in North America, directed largely at regional economic transactions. While these effects have been important, the provision of rule of law is fragmentary and has not produced the degree of spillover that was hoped for. Finally, we conclude by examining the future prospects of RPG provision in North America.

\section{Overview of the region before regional integration agreements}

Before 1988, US-Canadian economic cooperation was guided by the multilateral trade framework that the USA had promoted after World War II with the creation of the General Agreement on Trade and Tariffs (GATT). Both states were founding GATT members, unlike Mexico, which joined nearly four decades later. Until the negotiation of the US-Canadian FTA (CUSFTA), the USA showed a strong preference for global, multilateral economic RPGs. However, there were more limited earlier agreements, which can be seen as RPG inputs, produced in other areas. Between 1948 and 1992, when NAFTA negotiations began in earnest, Canada, the USA, 
and Mexico had signed 451 treaties between them, with more than 100 for each category of connectivity, peace and security, and natural resources and the environment (see Figure 13.1). ${ }^{3}$ Besides eliminating barriers to trade and investment, the basic purpose of CUSFTA, especially in the eyes of the Canadians, was to establish a dispute settlement system that eliminated highhanded unilateral actions from the USA.

While remaining outside the GATT, Mexico pursued an inward-looking, protectionist policy of import substitution, based on the ideas promoted by Raúl Prebisch and the United Nations' Economic Commission for Latin America and the Caribbean (ECLAC) that nations needed to industrialize to escape their "secularly deteriorating terms of trade" as commodity exporters. Mexico pursued a number of integration agreements with Latin America, such as LAFTA (1960) and SELA (1975), but none led to substantial economic integration or produced important RPGs. These failures contrast with the success, albeit limited to trade and investment, of NAFTA. The former were politically propelled and maintained protectionism, while NAFTA involved an open trade agenda, with few exceptions, that traded economic nationalism for an integrated trade and investment area.

Starting in 1988, Mexico's newly elected president Carlos Salinas sought to anchor recent market-friendly reforms through trade deals. Before turning to the north, Salinas had sought closer economic ties with Europe and

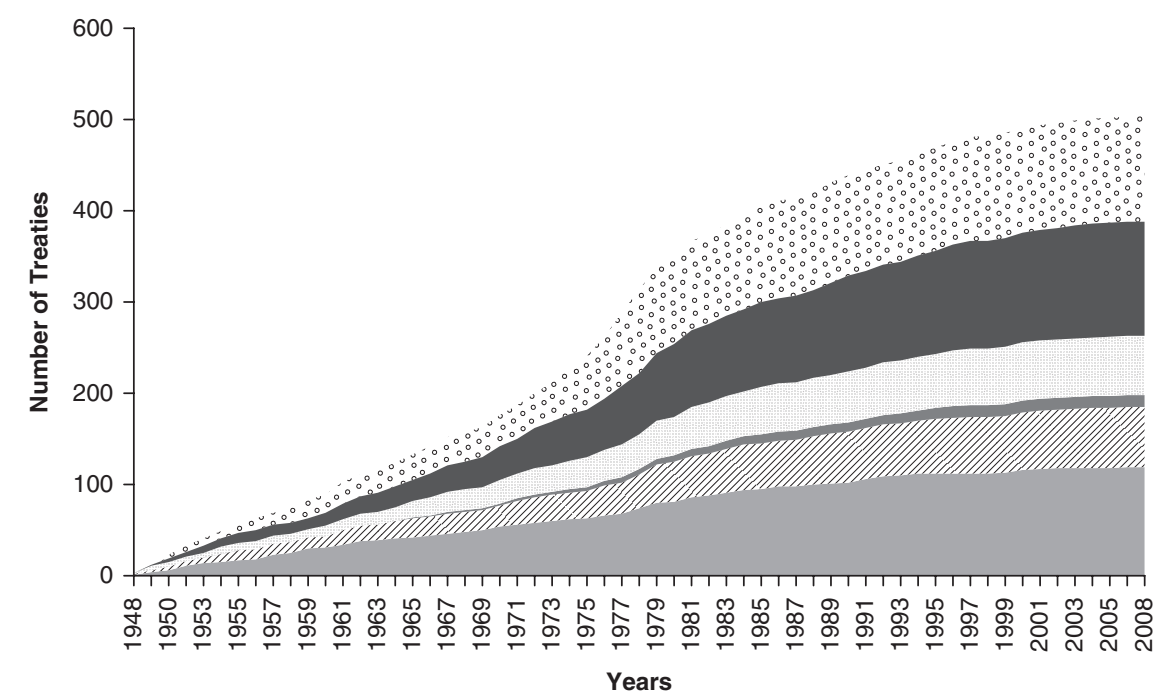

\begin{tabular}{|lll|}
\hline Connectivity & $\square$ Econ\&Integration & $\square$ Governance \\
$\square$ Human Development & Environment & $\square$
\end{tabular}

Figure 13.1 Total Treaties in North America.

Source: Liu and Kahn, Regional Public Goods Database (Chapter 2). 
Japan, only to be rejected by both. President George Bush, however, quickly accepted Salinas' request for a bilateral pact. The presidents-elect established a good personal rapport, dubbed the "spirit of Houston," after a meeting in the Texan city a few weeks before their respective inaugurations. In August 1990, President Bush indicated to Congress that he intended to move forward with a bilateral agreement, at which point Canada reversed its earlier reticence and asked to join (Boskin 2014). Thus began the three-nation North American economic region.

\section{The pursuit of NAFTA}

Although the Mexican government faced internal skepticism about free trade with the USA, Mexicans did not expect any serious opposition to the trade talks. However, US labor unions, human rights NGOs, environmental groups, populist politicians like businessman Ross Perot, the Congressional Black Caucus, and the right wing of the Republican Party opposed granting Bush fast-track authority to negotiate with Mexico. It became clear that the Mexican government had to engage in Congressional politics to overcome objections from opponents of free trade with Mexico - though few had expressed reservations about the earlier Canadian accord or ongoing GATT round. ${ }^{4}$

Once the fast-track vote was won and formal talks began, the negotiation proceeded at a rapid pace, though not fast enough to get NAFTA through Congress before the presidential election of 1992. When Bill Clinton unseated Bush, with help from anti-NAFTA crusader Ross Perot, who won 18.9\% of the vote, it opened a new phase in the formally completed negotiations. Responding to trade unions and environmental activists, Clinton insisted that NAFTA would include side agreements on these areas. These were finalized in September 1993, and the whole bill was sent to Congress. The House approved NAFTA by a slim margin of 34 votes on November 17; the Senate passed NAFTA three days later with 61 votes in favor and 38 against. NAFTA took effect on January 11994 (see Long 2015, chapter 4).

As stated in the agreement's objectives, the most important RPGs expected from NAFTA were in the following areas:

- The elimination of trade barriers and the facilitation of "the cross-border movement of goods and services" between the three nations.

- The promotion of "fair competition."

- Regional investment.

- Protection of intellectual property rights.

- Institutionalization of the agreement's implementation and administration, with mechanisms for dispute resolution (NAFTA Secretariat 1993).

Fulfilling these obligations in North America demanded a major transformation of the institutional and legal landscape, particularly for Mexico, whose standards had to catch up with those of the other two countries. Success was 
not evenly achieved, but trade and investment grew quickly in NAFTA's first decade (see Figure 13.2). The dispute resolution system created by the agreement has worked remarkably well.

The first RPG that surfaced unexpectedly in the region was the result of the currency crisis that hit Mexico in December 1994, when unprecedented political violence caused jitters in the financial markets. A combination of these fears, plus the ensuing issuing of large amounts of US-dollar-denominated shortterm debt, an insufficiently flexible exchange rate system, and the inexpert management of the situation by a rookie administration, led to a devaluation in which the Mexican peso lost two-thirds of its value against the US dollar, causing panic in the financial and foreign exchange markets. The risk that this situation would get out of control less than a year after NAFTA came into force drove President Clinton to skirt Congress and prepare an unprecedented US $\$ 50$ billion rescue package based on the Exchange Stabilization Fund and resources from the IMF, the World Bank, Canada, the European Union (EU), and Japan. The crisis rapidly dissipated and, after a deep recession, Mexico began to grow again within six quarters and repaid all its debt in 1997, well ahead of schedule. It is doubtful whether the USA would have undertaken this rescue operation had it not been for NAFTA.

Bolstered by RPGs in trade, rule of law, and macroeconomic stability, the creation of NAFTA achieved remarkable success in its first seven years. Between 1994 and 2001, its share of the global GDP went from 30\% to 36\%, as all other regions of the world lost ground. The EU fell by 1 percentage point, to $25 \%$, despite having increased its membership; Asia ${ }^{5}$ went from $25 \%$

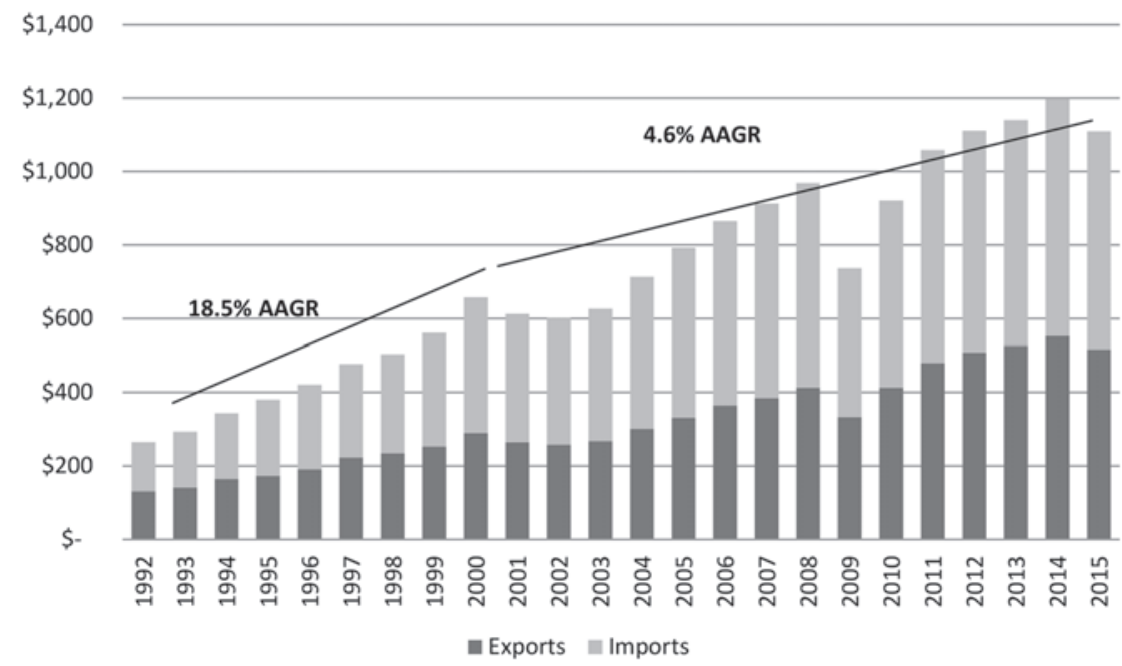

Figure 13.2 US Trade with North America (billions of US\$).

Source: Pastor (2011, p.25). 
to $22 \%$; while the rest of the world lost 2 percentage points to reach just $17 \%$ of the total in 2001. In this period North America emerged as a formidable region that exceeded the EU in terms of economic size and productivity. The three economies and societies were progressively connected by trade, investment, pipelines, tourism, and immigration (see Figure 13.3). In early 2001, the presidents of Mexico and the USA proposed a North American economic community. In April they traveled to Canada to consult with its prime minister: "It seemed like the high point of North American integration, and as it turned out, it was" (Pastor 2011, p.23).

By the end of 2001, the North American landscape had dramatically changed. The continental economy slowed with the end of the dot-com boom in the USA. The downturn was amplified by the terrorist attacks of September 11 2001. Instead of responding regionally, the USA tightened its own borders, which slowed trade during a recession. The attacks led to a surge in nationalist, frequently nativist, sentiments that undermined efforts to find regional solutions regarding security — such as the Security and Prosperity Partnership-or migration. Perversely, as the need grew to better manage massive transnational flows, improve security, and enhance rule of law, the willingness of the three governments and their publics to produce them faded. The results of these failures are not encouraging. It is estimated that the region's share of the world's GDP in 2015 is between $25 \%$ and $27 \%$, depending on the level of the exchange rates of their three currencies, a serious drop from the $36 \%$ reached in 2001. The three governments have largely failed to use NAFTA as a platform on which to build a more competitive region and address a new agenda beyond that of the trade agreement's mandate.

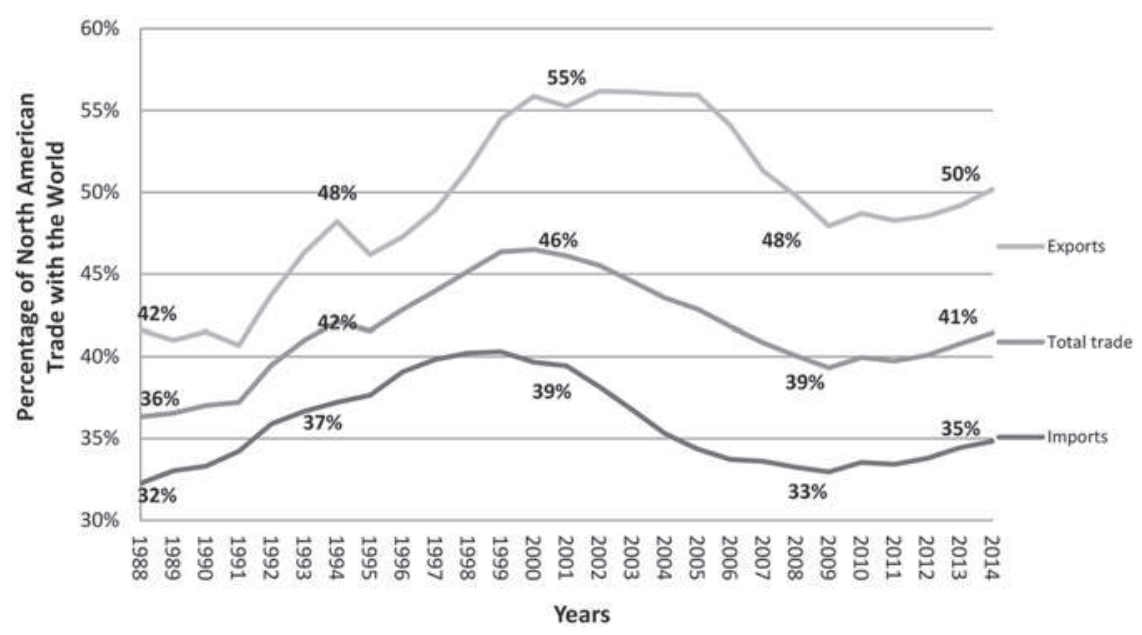

Figure 13.3 Integration: Intra-North American Trade as Percentage of North American Trade with the World.

Source: Pastor (2011, p.27). 


\section{RPGs in North America}

Since NAFTA, transnational flows of nearly every variety have grown dramatically; however, the response has not always been regional in nature. North America's founding document is firmly situated in national principlesNAFTA's negotiators avoided hints of supranationalism. NAFTA's founding document makes it clear that none of the parties sought an expansive regionalism (Long 2014; Cameron and Tomlin 2000). Since the mid-2000s, trilateralism has frequently been replaced by dual-bilateralism. In a sense, this is a return to an historical pattern in North America. According to UN registries, there is only one trilateral treaty in North America — a 1976 environmental treaty. (NAFTA is not a treaty, so it is not included, signaling limitations with the data.) Mexico and Canada have only reported six bilateral treaties since 1948. However, the USA has 281 treaties with Canada and 216 with Mexico (see Figure 13.4). ${ }^{6}$

Despite NAFTA's national nature, it has led to the creation of important RPGs. We define RPGs in North America as a type of public good that "provides nonexclusive and nonrival benefits to individuals in a well-defined region" (this builds on Sandler 2004; Estevadeordal, Frantz, and Nguyen 2004; and Chapter 1 of this volume). Estevadeordal et al. (2004) note that RPGs are often an outcome of regional cooperation agreements, of which NAFTA was an early and widely copied example. The dramatic increases in trade and

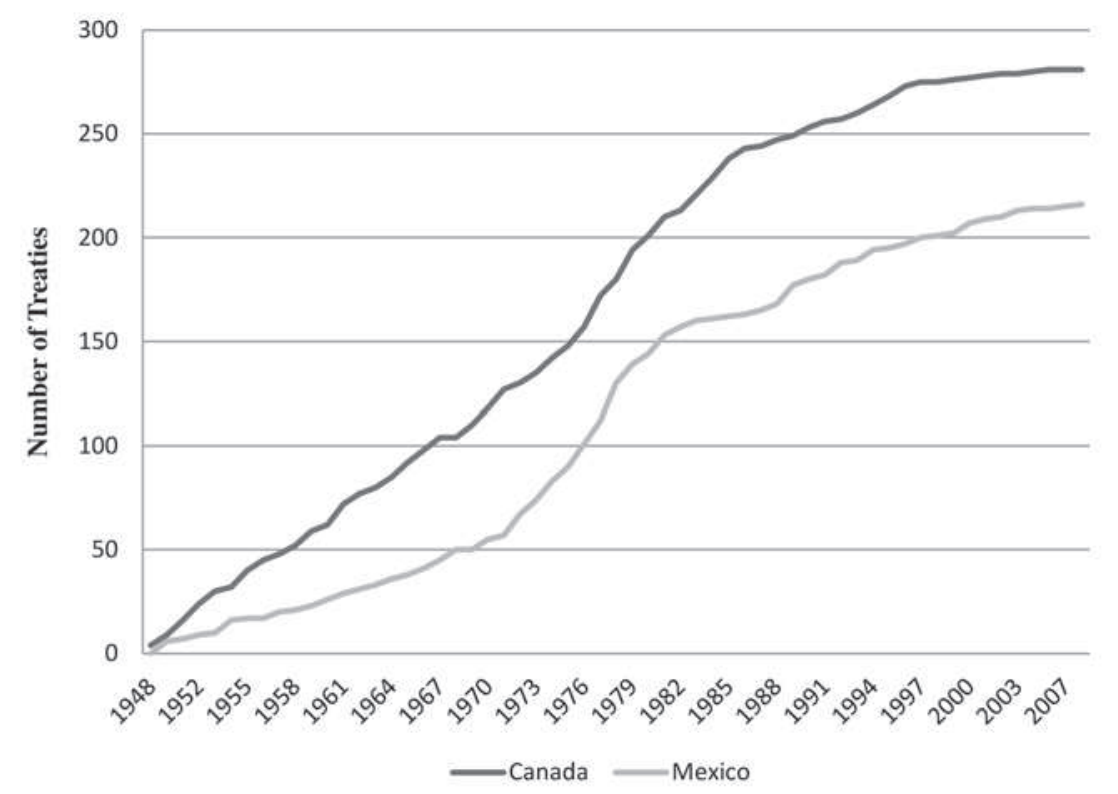

Figure 13.4 US Bilateral Treaties by Partner.

Source: Liu and Kahn, Regional Public Goods Database (Chapter 2). 
investment that came with NAFTA were accompanied by much larger flows of migration and illicit traffic, all of which affected the demand for and provision of RPGs.

In the North American context, it is particularly important to highlight the interplay across different levels of government as this is relevant to the demand for and production of RPGs. Domestic, not regional, problems have been a greater factor in Mexico's disappointing economic growth over the past two decades. RPGs are unlikely to be a panacea for problems of peace and prosperity. A more adequate approach should start with the question of complementarity: where can RPGs make positive contributions? (See Chapter 6.) As RPGs cannot resolve many fundamentally domestic issues, weak provision of public goods at the national level can lower levels of regional goods.

Sandler (2006, p.10) offers a framework for examining the "aggregation technology" for RPGs - in essence, how the nature of RPG provision varies depending on the type of impure public good. Two of the types of aggregation Sandler discusses are particularly relevant. Sandler describes "weighted sum" aggregation of RPGs - "provision is no longer perfectly substitutable among countries" (Sandler 2004, p.18). The creation and benefits of the RPG are not equally shared. Second, Sandler discusses "weaker link" public goods, which are diminished by the unequal creation of that good across the region. With weaker link goods, the lowest level of provision has the greatest impact on the overall level of the RPG. Sandler's framework provides a way to conceptualize the provision of rule of law as an RPG that is not uniform across geographies or levels of analysis.

Sandler's analysis remains regional; however, RPGs have local and national effects. Similarly, deficient governance at the local and national level may reduce the availability of goods across the region. In this case, the weaker link in the production of rule of law in many sectors occurs in Mexico, largely due to lower state capacity. Insufficient provision by Mexico affects the total benefits of the RPG available to people and businesses across the region, but harms Mexico most of all. This is clear in terms of transnational security, particularly in the criminal justice system: Mexico suffers most-in social and economic terms - from the weakness of rule of law. The deficit affects the entirety of North America (and Central America, too) with decreasing intensity as it radiates outwards. While additional contributions from other states in the region to this weaker link RPG may produce benefits, the effects will be unequally distributed.

\section{Rule of law as a regional public good}

Though rule of law has often been treated as a public good at the local and national levels, this has rarely been the case regionally. In this section, we examine the concept of rule of law as a weaker link good with partial overlap and limited spillover across local, national, and regional levels. Like the 
related concept of governance, rule of law displays certain similarities across levels of analysis: ${ }^{7}$ 1) public and transparent rules, 2) equivalent application of these rules, and 3) open and public decision-making procedures. At the national level, where rule of law has been most studied, Guillermo O'Donnell (2004) defined it as existing when "whatever law exists is written down and publicly promulgated by an appropriate authority before the events meant to be regulated by it, and is fairly applied by relevant state institutions including the judiciary ... the administrative application or judicial adjudication of legal rules is consistent across equivalent cases; is made without taking into consideration the class, status, or relative amounts of power held by the parties in such cases; and applies procedures that are pre-established, knowable, and allow a fair chance for the views and interests at stake in each case to be properly voiced."

There are at least three reasons to consider regional rule of law in North America. Rule of law provides social order. There is a long tradition in International Relations of considering "international society" (Bull 1977, 1984, and Hurrell 2007), and the stronger web of connections makes the regional level even more "social." NAFTA also spurred more frequent and institutionalized interactions of officials among the three countries (Aspinwall 2009). NAFTA created clearer rules to structure transactions between and among member states, providing clarity at the regional level for trade and investment. Second, NAFTA created procedures that resolve some of the disputes that can arise from these transactions (completing equivalent application and openness as part of rule of law). Institutionalized dispute resolution replaces the threat of arbitrary US protectionism with regional rule of law, through which all three countries benefit. Finally, regional rule of law has enhanced, albeit imperfectly, the rule of law at the domestic level. In transnational cases, business disputes can be settled in the courts of the country of the claimant's choosing. Through this, Mexico "borrowed" the US judiciary and rule of law for some issues, thereby bringing a regional dimension even to domestic rule of law in the three countries.

NAFTA sought to promote a partial spillover from the regional level to the Mexican domestic context. While RPGs may partially overcome deficits at the national and local levels, this spillover exists unevenly across geographies and issue areas. Deficits at local and national levels also undermine regional rule of law. Like many goods, the demand, production, and consumption of rule of law are not evenly distributed across the North American region. Nor has this good been evenly distributed among social and economic sectors.

\section{The rule of law as a regional public good: the case of Mexico}

North America's prospects could be improved by enhancing the production of RPGs, such as rule of law. Among the countries of North America, it remains clear that Mexico has the least reliable legal system and weakest rule 
of law. While NAFTA contributed to an improvement in rule of law for some sections of the economy, for much of the population the situation has become worse. The share of employment in the "modern" sector, defined by size as firms employing 500 workers or more, has remained constant in the period mentioned at $20 \%$ of the labor force; the share of the "traditional" firms, with 10 employees or less, has grown from $39 \%$ to $42 \%$; while the segment in between these, firms with 11 to 500 employees, which could be characterized as the bridge connecting the two, has seen its share fall. The falling productivity of the traditional part of the economy has resulted in wages for low-skilled workers that fell between 1999 and 2009 by $2.4 \%$ per year, while the salaries of the workers in the "modern" segment have remained stagnant despite the impressive gains in productivity (Bolio et al. 2014). Stagnant or falling wages are not what was expected from North America economic integration. The deepening split between modern and traditional also has a geographic dimension, since the former are located in the north and center of the country, closer to the US border and with much better physical and social infrastructure, while the latter are concentrated in the south. In this sense, NAFTA resulted in deepening the division of the country into two segments: one that prospers and grows, and another which remains impoverished.

Mexico's market-oriented reforms of the 1980s and 1990s, as profound as they appeared to be, did not alter longstanding institutional weaknesses. The reforms were full of contradictions. Despite their liberalizing logic, some sectors remained protected from international competition. Privatizations did not adequately consider the transformation and better integration of the economy's structure. Many regulations were eliminated, but others continued to stifle innovation, and subsidies did not disappear. In the face of entrenched interests and political opposition, Mexico's reform process largely stagnated. When the PRI returned to power in 2012, President Peña Nieto (whose term in office is due to expire in 2018) forged a political coalition behind a "Pact for Mexico," to advance energy, fiscal, telecommunications, education, and other reforms (Sada 2013). The energy reform welcomed private and foreign investment to the oil and gas business in Mexico for the first time in almost 80 years and increased competition in the electrical sector. This reduced the dominance of state-owned monopolies Petróleos Mexicanos and the Federal Electricity Commission in those key sectors. The reforms follow NAFTA's logic of bringing strategic areas under the cover of the US legal system to assure foreign and domestic investors. It is too early to assess the reforms' political sustainability and economic effects; some reforms, including energy and education, have drawn determined opposition as the president's approval ratings have deteriorated. However, the opening of key sectors excluded from NAFTA may provide momentum for closer regional integration, especially in energy.

Though much of its production has come via externalities or has been ad hoc, North America has some multilateral institutions that contribute to regional 
rule of law. First, NAFTA created panels for trade dispute resolution. Second, NAFTA created clearer rules for investment and institutionalized mechanisms for the settlement of disputes between investors and the states-party. These new mechanisms expanded the rule of law, primarily for international businesses and investors, though also to Mexican firms associated with foreign investors in complex supply chains. The agreements help to keep politics at arms' length in state-investor disagreements (Brower 2015). Third, NAFTA created some (weak) mechanisms, through which citizens and civil society groups can appeal at the international level in pursuit of compliance with national law and NAFTA obligations. These mechanisms enhanced the clarity of regional transactions, serving as a "club good" for economic actors within the three countries, promoting intra-North American investment. However, regionally produced rule of law primarily benefits only the sectors of those societies that are engaged in licit international transactions. It does not provide the same benefits to regions with low participation in international transactions, nor does it address the worrying trade in illicit goods among the three countries, mostly between Mexico and the United States. These are, mainly, illegal drugs and illegally trafficked people from the south flowing north and weapons and money from the north flowing south. The overall economic magnitude of illicit trade is unknown, for obvious reasons, but official estimates place the USA-Mexico drug trade at about $5 \%$ of the amount of legal bilateral trade in goods and services, which will approach US $\$ 600$ billion in $2016 .{ }^{8}$ Although law enforcement officials of both countries believe that the enormous growth in legal trade can help mask the illicit flows, particularly facilitating cash transfers and money laundering, trade experts have pointed to closer, more effective cooperation between the United States and Mexico, engendered by legal trade flows. More to the point, the expansion of this illicit trade, and the violence and corruption surrounding it, weakens the benefits of rule of law as a regional public good.

Dispute resolution mechanisms were important for all the actors involved, though in different ways. Mexico and Canada worried primarily about whether the USA - particularly a protectionist Congress - could undermine their gains in market access through unilateral measures, as we saw when President Obama adopted "buy American" provisions at the start of the Great Recession that are illegal under NAFTA. At the time, the USA and Canada sought investment protections and dispute resolution because of concerns about the political climate and weak judicial system in Mexico, and US investors worried about the risk of expropriation in Mexico and protection of intellectual property. These concerns were crystallized in two separate parts of the agreement, Chapters 11 and 19.

NAFTA's chapter 11 sought to regionalize and rationalize disputes between states and investors. For decades, when companies had grievances about their investments in other countries, they sought the protection of their home government, hoping to gain diplomatic pressure on their behalf. This took the dispute out of the legal and economic realms and placed it squarely in the 
political. Transparency and predictability suffered. Handling grievances under national courts - a principle long advanced in Latin America dating back to the Drago and Calvo doctrines-offered little assurance to investors if these courts were viewed as subject to political influence or as biased toward national actors. Put differently, chapter 11 was intended to bring the rule of law to these disputes, understood as the fair and consistent application of transparent, public, pre-existing rules. As Brower (2015) wrote: "a rule-based system must have an enforcement mechanism if its substantive rules are to have any meaning over the long term."

The evolving nature of investor-state disputes demonstrates that rule of law concerns were not limited strictly to Mexico. In recent cases, Canadian provincial and local regulations have been seen as injuring foreign investors, drawing criticism from Canadian activists (Sinclair 2015). Through the end of 2014, there had been 77 investor-state disputes under chapter 11. Canada has been the subject of the greatest number of claims (35), though Mexico has paid a larger share of judgments (US\$204 million). While there are debates about whether these rulings have infringed on governments' legitimate regulatory powers, the existence of a clear framework seems to have favored investment. In Mexico, where there was the greatest initial concern about transparent dispute settlement, nearly $60 \%$ of total inward FDI has originated from NAFTA partner countries, according to data from UNCTAD. This happened even as total inward FDI in Mexico increased more than 17 times from 1990 to 2013. Canada's increase has been nearly as dramatic (see Figure 13.5).

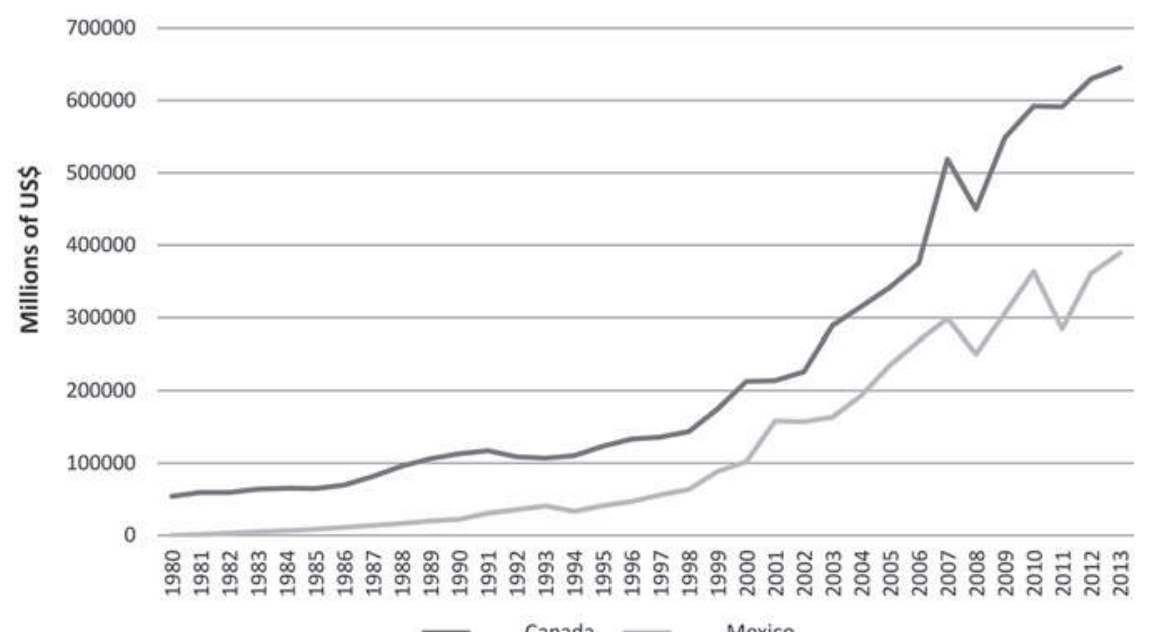

Figure 13.5 Inward FDI Stock, 1980-2013.

Source: Compiled by authors based on UNCTADstat, Foreign Direct Investment: Inward and Outward Flows and Stock Databse, http://unctadstat.unctad.org/ 


\section{The limits of regional rule of law}

The ability to resolve disputes pacifically at the regional level has not created spillover in terms of Mexico's ability to resolve disputes among its citizens with regularity and transparency. Mexico performs very poorly for various indicators related to rule of law and impunity. The country lacks the appropriate judicial infrastructure and rates of prosecution for crime are extremely low. A recent study on impunity noted that Mexico has just four judges for every 100,000 residents-less than a quarter of the average for the 59 countries involved in the study and half the rates for the USA (9.8) and Canada (8.4). ${ }^{9}$ As the country has turned to the military to battle drug trafficking, extrajudicial punishment seems to be a growing problem and human rights abuses have become a source of serious concern. Similarly, a number of recent tragic incidents have revealed the depth of cartels' and gangs' penetration into local political systems, irrespective of which political party is in charge. The impact of these struggles goes beyond the local level.

According to the World Bank's estimates, rule of law in Mexico improved significantly around 2000, as the government transitioned for the first time to the opposition center-right National Action Party (PAN). This estimate declined as drug-related violence increased from 2006-2007 under the stewardship of a second PAN administration. Within this composite indicator, Mexico's scores on government effectiveness and regulatory quality have seen moderate increases, although they are offset by indicators related to violence (see Figure 13.6). These figures appear to blend two divergent trends in the Mexican economy.

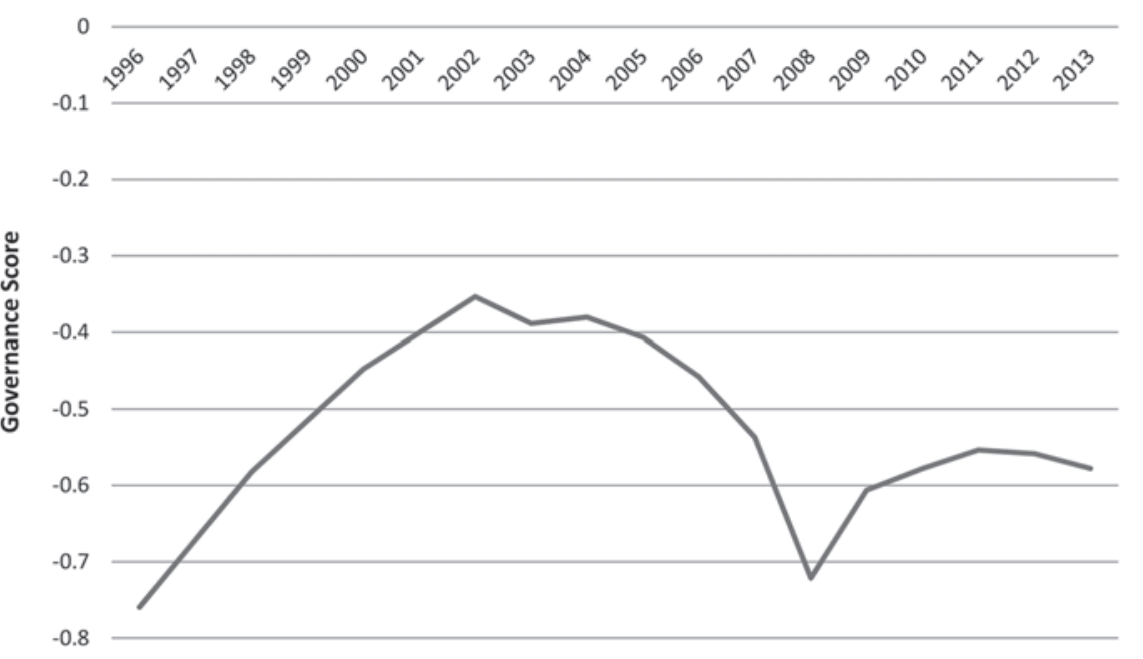

Figure 13.6 Rule of Law in Mexico.

Source: Worldwide Governance Indicators, World Bank DataBank. 
Challenges with rule of law, whether national or regional, are not limited to Mexico. This is clearly visible in the dysfunctional US immigration system, where high levels of undocumented immigration create public "bads" with impacts across levels of governance, including for shaping more effective tax, social service, and labor market policies. As with many such issues, the need for RPGs in rule of law is directly linked to the expansion of transnational flows. While NAFTA created a regional market for goods, and to a lesser but important extent for services and capital, it did not legally unify labor markets.

As Estevadeordal et al. (2004, p.6) note, national commitments are crucial for adequate RPG creation. "If states are unwilling to envisage a role for regional cooperation to promote national development, it is unlikely that RPGs will be supplied at optimal levels." When one observes the current political scenario of North America, it is difficult to avoid skepticism about the likelihood of a more united North America. There is neither the interest nor the necessary attention on the part of the governments in question, with the possible exception of Mexico, which is immersed in a deep process of economic reforms and whose government is mired in a delicate political situation with very low approval from the population, which distract it from regional integration. While Trudeau favors multilateralism more than his predecessor, the emphasis on bilateral USA-Canada ties remains. For their part, US politicians have more often referred to NAFTA as a scapegoat, not as a framework for regional responses to shared problems.

\section{Central RPGs: past production and future prospects}

In Chapter 2, Liu and Kahn divide RPGs into six functional categories. While we have focused on the rule of law, in closing we will address other RPGs produced-or lacking - in each of these functional categories.

\section{Economic cooperation and integration}

NAFTA's focus was on the production of RPGs in trade and investment. At the regional level, these RPGs have produced greater prosperity, though with unequal distribution. However, trade and investment have not been the only economic RPGs in North America. At the macro level, there has been significant convergence among the three economies in terms of business cycles and interest rates, leading to a more predictable environment for companies that produce, invest, and trade in North America (Serra Puche 2015). NAFTA did not include formal agreements to coordinate fiscal and monetary policies, but informally communication among the treasuries and the central banks of the region is important. While for the most part convergence has been an externality of closer links among the three economies, it has at times been intentionally supported by government actions - most crucially in the significant US backing of Mexico during its 1994 peso crisis (De Long, De Long, and Robinson 1996; Edwards 1998). 
Transnational production chains have been a significant, only partially anticipated aspect of NAFTA. About $40 \%$ of the value added in Mexican exports to the USA was produced in the USA (Wilson 2011). Mexican firms have benefited from their insertion into the regional economy, growing more competitive and productive through the adoption of modern business practices. However, the regional economy contributes to a bifurcation between the regionally and globally active and the purely domestic. Talent and capital are available to the former while being drawn away from the latter. In Mexico, this has been reflected in the growth of employment in the informal economy $(60 \%$ of the workforce, by some measures, but just a quarter of the GDP) (Flores 2014) where productivity has declined. By definition, this huge informal sector is an area where the rule of law is largely absent and the provision of RPGs has very little effect. RPGs cannot entirely substitute the need to produce similar public goods at the national and subnational levels.

\section{Human and social development}

Despite their proximity, educational exchanges in the region have been lacking. The number of students who study abroad in another North American country trails behind the numbers of those who head farther afield. Canada and Mexico combined to send about 72,000 students to the USA-fewer than Saudi Arabia, and far fewer than Asia, which sent a whopping 839,000. ${ }^{10}$ As Robert Pastor frequently pointed out, there are hundreds of academic research centers in North America dedicated to other areas of the world, but few that focus on North America. ${ }^{11}$ Support for greater educational exchanges among the three countries would create important RPGs. The leaders have recognized this need, pledging in 2016 to create the North American Center for Collaborative Development, based at the University of Arizona's Consortium for North American Higher Education Collaboration. Its promotion of research on shared challenges is sorely needed, though the commitment of funds and leadership is not yet clear. Summit pledges also included greater educational exchanges and programs to boost indigenous education and women's entrepreneurship (White House 2016).

RPG production has been more effective in certain professional areas, such as epidemiology. Governmental, academic, and private-sector actors in the health field undertake extensive planning and preparation to contain possible outbreaks of disease. There is close communication and collaboration among the three countries, thus mitigating one possible negative externality of increased regional flows. A 2007 plan created under the defunct Security and Prosperity Partnership helped guide the three countries' responses to a 2009 outbreak of H1N1 influenza. The plan has been augmented with lessons learned ${ }^{12}$ and to address emerging diseases including Zika and chikungunya (White House 2016). 


\section{Natural resources, environment, and energy}

North America has been defined by the extensive borders between the USA and its neighbors in terms of both the threats and opportunities that these entail. This is particularly clear regarding environmental challenges and opportunities for energy sector cooperation. Long before NAFTA, regional agreements sought to manage shared border resources and to limit transnational pollution.

Some of the stronger intergovernmental organizations to emerge from NAFTA concern environmental issues, where the challenges are very clearly transnational and sovereignty concerns have been less pronounced. Two merit mention: the North American Development Bank (Nadbank) and the Commission for Environmental Cooperation (CEC). The Nadbank has limited funding and a restricted mandate, but it has financed nearly 200 projects that address environmental and health issues on the USA-Mexico border. Though the CEC lacks sharp teeth-deliberately so according to the terms of NAFTA's environmental side agreement — it has provided a venue for appeals from civil society to the international level. NGOs can use the CEC to challenge national governments over the perceived failure to implement national environmental legislation. Though it lacks the power to sanction, the CEC's reports have served as a means to pressure governments into compliance.

In recent summits, North American leaders have forged a commitment to build upon Mexican energy reforms and the growth of energy production in the USA and Canada to create a more secure, integrated, and green North American energy market (White House 2015, 2016). Perhaps the biggest headlines from the 2016 Ottawa summit involved increasing clean energy production, boosting efficiency standards, and working to implement the Paris climate accords. While Mexico has sought to lead on the issue in its diplomacy and radical pledges to reduce $\mathrm{CO}_{2}$ emissions, and Canada's new leadership has made bolder commitments on climate, the ability of the United States to deliver is complicated by sharp partisan divisions.

At a meeting of energy ministers in December 2014, the three countries sought to develop a regional comparative advantage in energy. This focused on "three strategic areas": joint statistics and mapping of energy resources and infrastructure; unconventional oil and gas; and modernization of energy infrastructure, institutions, and innovation (Natural Resources Canada 2014). Given the widespread impact of energy on both the economy and the environment, this should remain an important area for RPGs.

\section{Peace and security}

At the level of traditional interstate security, North America resembles Karl Deutsch's concept of a security community. There are no serious preparations for interstate conflict and there is an expectation that disagreements will be settled without resorting to threats of, or the use of, force (Deutsch 1957), with the possible exception of the Republican nominee for president being elected 
in November 2016. However, the existence of a high-level security community has not lessened the impact of transnational and human security concerns, which have become even more salient in recent years. Both the importance and limitations of RPG rule of law can be seen in transnational security, a key challenge for Mexico, in which the USA is particularly involved as the largest market for drugs and a provider of illicit arms and official security support.

There has been significant regional cooperation is terms of transnational security. However, these problems make clear that the limits of spillover vary from one level of governance to another. US efforts to control drug trafficking in Mexico in cooperation with the Mexican government have had no discernible effect on the level of traffic. Policy coordination has been effective in some regards, such as intelligence cooperation aimed at capturing cartel leaders. However, it has been noticeably absent in others, such as in the control of southbound arms shipments.

The strategy of aggressive policing has produced, at least in the short term, greater human insecurity — and tremendous human and economic costs — without notable improvements to the rule of law (Kenny, Serrano, and Sotomayor 2012). According to official government statistics, impunity has actually worsened: nearly $94 \%$ of crimes are not reported or investigated. This figure was nearly as high for crimes against businesses, of which $88 \%$ were not reported or investigated. While Mexico has more police per capita than the international average, ${ }^{13}$ just $22 \%$ of Mexicans have some or much confidence in the police, according to a December 2014 poll by the newspaper Reforma (Grupo Reforma 2014). Nearly half of prisoners are being detained without having been sentenced.

Insecurity is the most blatant manifestation of inadequate rule of law. About one-third of surveyed Mexican households reported having at least one person who was a victim of a crime in 2014; only a fraction are officially reported. Security concerns have a tremendous impact on Mexican businesses, too, which face a national average cost of more than MXN55,700 (equivalent to an average US\$3,840 in 2015) annually as a result of crime and security measures (INEGI 2014). However, there is a huge subnational variation, with costs ranging as high as MXN90,000 per business unit in the aerospace hub of Querétaro (INEGI). According to the same agency, one-third of economic units (a category that includes both formal and informal goods and services providers of all sizes, including many micro-enterprises) reported being victims of crime in 2013. In this, too, there is a tremendous geographical variation, ranging from $21 \%$ in the state of San Luis Potosí to $44 \%$ in Baja California. Robbery, corruption, and extortion were the most common crimes against business. Combined, INEGI estimates that crime costs households and businesses about $2 \%$ of GDP each year.

\section{Connectivity}

Insufficient investment in various aspects of connectivity has limited North America's ability to take advantage of its shared geography. This has been 
most notable in inadequate physical infrastructure, which has been strained by the massive expansion of trade flows. New and expanded crossings are needed, but have stalled. A long-planned new bridge for the world's most valuable border corridor, between Detroit and Windsor, is years behind schedule. Rail connections between the USA and Canada are outdated, even as they deal with tremendous quantities of freight. The planned Keystone XL pipeline has been shelved for the immediate future. Mexico's rail system, after decades of neglect, has received increased attention, although a new rail crossing on the USA-Mexico border opened only after years of delays. In many cases, connectivity worsened after 2001 due to the "thickening" of US borders (Pastor 2011), lessening the region's geographic advantages. This was exacerbated by policies that limited cross-border trucking between Mexico and the USA (in clear violation of the corresponding NAFTA provisions), and created expensive cabotage restrictions to American-flagged vessels in the USA resulting from the Jones Act, a remnant of Prohibition. The 2014 North American Leaders Summit called for a North American Transportation Plan as a "key deliverable," but this has not materialized. The 2016 summit omitted mention of costly physical infrastructure and instead focused on deploying technology to make crossing more efficient-a welcome, but probably insufficient step. The lack of infrastructure is replicated in other areas. Among OECD members, Mexico has the second-lowest number of fixed broadband internet subscriptions per 100 residents. The USA is number 16 of 34 countries; Canada is number 12. All lag even further behind in faster fiber-optic connections. There have been a number of recent positive steps, like the binational airport crossing in Tijuana-San Diego; the agreement to allow customs officials to do pre-clearing in the other country's territory; state-of-the-art customs-checking facilities going to Mexico; and trusted traveler programs and some improvements in screening procedures. However, for the most part these welcome developments barely compensate for post-9/11 border thickening instead of advancing the region beyond where it was 15 years ago. A lot more needs to be done if North America retains its role of the most productive region on earth.

\section{Governance and institutions}

In governance and institutions, North America diverges clearly from the European model. Some of the thin institutions of NAFTA, such as the labor secretariat, have been allowed to expire. Less formal gatherings, such as the North American Leaders Summit, have been infrequent and subject to political whims. And given the political discourse prevalent in the presidential campaigns of 2016, the chances of advancing a regional agenda appear dim.

From the perspective of RPGs, the crucial question for North America concerns multilevel governance. How can the regional level better promote the creation of RPGs that penetrate to national and subnational levels? Up to this point, the approach has been the opposite: how to lessen the impact of failures 
of governance and lack of rule of law at the subnational and national levels on regional transactions. The national and subnational weakness in rule of law presents a particular problem for North America, because regional institutions have few supranational capacities. Instead they rely heavily on national enforcement. However, NAFTA changed the landscape, creating new demands for cooperation. "[I]ncentives for cooperation in providing RPGs are greater when there are economic incentives and commercial interests in place" (Estevadeordal, Frantz, and Nguyen 2004). Certainly, these incentives and interests exist in the case of North America, but for the most part, efforts to produce RPGs have been ad hoc. Where they have been institutionalized, they have been thin and have reached across various levels of governance. Creating institutions that fulfill this role without overly impinging on the sovereignty of the three countries that have traditionally guarded it zealously is a difficult task.

\section{Conclusions}

In conclusion, North America's emergence as a region, and its production of RPGs, has been at once exemplary and incomplete. For the previous century, it has been a zone of interstate peace, but regional, transnational flows contribute to high levels of violence. It was a leader in regional trade integration, but that integration did not produce widely shared prosperity. Opponents of deeper regionalism have often stressed a desire to avoid Europe's bureaucratic model. However, they present a false choice: North America does not need larger bureaucracies to benefit from regionalism, but it does need greater political and fiscal investment in the creation of RPGs to manage shared problems and to enhance the foundations of shared prosperity. The opportunities for even incremental improvements in cooperation are substantial, even as the very basis of regional cooperation faces its greatest political challenges since the ratification of NAFTA.

\section{Notes}

1 For example, Deutsch (1957) discussed the USA and Canada as a security community. During the Cold War, air-defense institution NORAD did not include Mexico, which was instead included in Latin American defense pacts.

2 See the Regional Public Goods Database described by Liu and Kahn in Chapter 2 of this volume.

3 See footnote 2 .

4 The Mexican government undertook an unprecedented campaign throughout the USA, targeting the population of all congressional districts that had representatives that were undecided on the NAFTA issue, and encouraging them to write their member of congress in support of free trade with Mexico. The country spent US $\$ 50$ million on such lobbying between 1990 and 1993.

5 Defined as including Japan, China, Hong Kong, Taiwan, South Korea, and the ten ASEAN nations.

6 See footnote 2.

7 On governance across levels of analysis, see Krahmann (2003). 
8 Melissa Dell (2015) recently noted the variety of estimates of Mexican drug trafficking organizations' earnings in the US market. The State Department's own estimate ranges from US $\$ 13.6$ to US $\$ 48.4$ billion per year, with similar estimates from other US and Mexican government agencies. This stands in stark contrast to the estimated US\$560 million in domestic sales in Mexico.

9 See Le Clercq Ortega, Antonio, and Rodríguez Sánchez Lara (2015) and "Judicial Systems," Citizen Security Statistics for the Americas, database, Organization of American States. Online: www.oas.org/dsp/observatorio/database/indicatorsdetails. aspx?lang=en\&indicator $=48$

10 Data from US Immigration and Customs Enforcement, "SEVIS by the numbers," October 2014. Online: www.ice.gov/sites/default/files/documents/Document/2014/ by-the-numbers.pdf

11 This was a frequent complaint in Pastor's many books and articles, such as The North American Idea (2011, p.191). See also Gueorguieva (2007).

12 See the "North American Plan for Animal and Pandemic Influenza," April 2012. www.phe.gov/Preparedness/international/Documents/napapi.pdf

13 "Indice global de impunidad," Centros de Estudios sobre Impunidad y Justicia. www.udlap.mx/cesij/resumenejecutivo.aspx

\section{References}

Aspinwall, Mark. 2009. "NAFTA-Ization: Regionalization and Domestic Political Adjustment in the North American Economic Area." Journal of Common Market Studies 47: 1-24.

Bolio, Eduardo, Jaana Remes, Tomás Lajous, James Manyika, Morten Rossé, and Eugenia Ramirez. 2014. "A Tale of Two Mexicos: Growth and Prosperity in a Two-Speed Economy.” London: McKinsey Global Institute.

Boskin, Michael J., ed. 2014. NAFTA at 20: The North American Free Trade Agreement's Achievements and Challenges. Stanford, CA: Hoover Institution Press.

Brower, Charles N. 2015. "Who Then Should Judge? Developing the International Rule of Law under NAFTA Chapter 11.” Chicago Journal of International Law 2, no. 1.

Bull, Hedley. 1977. The Anarchical Society: A Study of Order in World Politics. New York: Columbia University Press.

Bull, Hedley. 1984. The Expansion of International Society. London: Clarendon Press.

Cameron, Maxwell A., and Brian W. Tomlin. 2000. The Making of NAFTA: How the Deal Was Done. Ithaca, NY: Cornell University Press.

Dell, Melissa. 2015. "Trafficking Networks and the Mexican Drug War." The American Economic Review 105:1738-79.

De Long, Bradford, Christopher De Long and Sherman Robinson. 1996. "The Case for Mexico's Rescue: The Peso Package Looks Even Better Now.” Foreign Affairs 75: 8.

Deutsch, Karl Wolfgang. 1957. Political Community in the North Atlantic Area. Princeton, NJ: Princeton University Press.

Edwards, Sebastian. 1998. “The Mexican Peso Crisis: How Much Did We Know? When Did We Know It?” The World Economy 21, no. 1: 1-30.

Estevadeordal, Antoni, Brian Frantz, and Tam Robert Nguyen. 2004. Regional Public Goods: From Theory to Practice. Washington, DC: Inter-American Development Bank.

Flores, Zenyazen. 2014. "Economía informal representó 26\% del PIB de 2003 a 2012: Inegi." El Financiero. July 30. www.elfinanciero.com.mx/economia/informalinformalidad-pib-inegi-eduardo-sojo.html

Grupo Reforma. 2014. "Disminuye confianza en instituciones.” Reforma. December 12. http://gruporeforma-blogs.com/encuestas/?p=5233 
Gueorguieva, Vassia. 2007. "North American Studies Centers: An Overview." Norteamérica 2, no. 2.

Hurrell, Andrew. 2007. On Global Order: Power, Values, and the Constitution of International Society. Oxford and New York: Oxford University Press.

Institución Nacional de Estadística y Geografia (INEGI). 2014. "Encuesta Nacional de Victimización de Empresas." Online database. www.inegi.org.mx/est/contenidos/ Proyectos/encuestas/establecimientos/otras/enve/2014/default.aspx (accessed May 9 2016).

Kenny, Paul, Mónica Serrano, and Arturo Sotomayor. 2012. Mexico's Security Failure: Collapse Into Criminal Violence. New York: Routledge.

Krahmann, Elke. 2003. "National, Regional, and Global Governance: One Phenomenon or Many?” Global Governance 9, no. 3: 323-346.

Le Clercq Ortega, Juan Antonio, and Gerardo Rodríguez Sánchez Lara. 2015. "Índice global de impunidad, 2015." Puebla, Mexico: Universidad de las América. www. udlap.mx/cesij/files/IGI_2015_digital.pdf

Long, Tom. 2014. "Echoes of 1992: The NAFTA Negotiation and North America Now." Washington, DC: Woodrow Wilson Center for International Scholars. www.wilsoncenter.org/sites/default/files/Long_NAFTA_and_Now_0.pdf

Long, Tom. 2015. Latin America Confronts the United States: Asymmetry and Influence. Cambridge and New York: Cambridge University Press.

NAFTA Secretariat. 1993. North American Free Trade Agreement, Article 102. www. nafta-sec-alena.org/Home/Legal-Texts/North-American-Free-Trade-Agreement

Natural Resources Canada. 2014. "News Release: Canada, United States and Mexico Enhance Leadership on North American Energy Cooperation." December 15. http://news.gc.ca/web/article-en.do?nid=914629

O’Donnell, Guillermo. 2004. "Why the Rule of Law Matters." Journal of Democracy 15, no. 4: 32-46.

Pastor, Robert A. 2011. The North American Idea. Oxford: Oxford University Press.

Sada, Andres. 2013. "What Is the Pacto por México?" Council of the Americas. March 11, 2013. www.as-coa.org/articles/explainer-what-pacto-por-méxico

Sandler, Todd. 2004. "Demand and institutions for regional public goods." In Regional Public Goods: From Theory to Practice, edited by A. Estevadeordal, B. Frantz, and T.R. Nguyen. Washington, DC: Inter-American Development Bank.

Sandler, Todd. 2006. "Regional Public Goods and International Organizations." The Review of International Organizations 1, no. 1: 5-25.

Serra Puche, J. 2015. NAFTA and the Making of a Region. Mexico City: Fondo de Cultura Económica.

Sinclair, Scott. 2015. "NAFTA Chapter 11 Investor-State Disputes to January 1, 2015." Canadian Centre for Policy Alternatives.

White House. 2015. "Joint Statement: United States-Mexico High Level Economic Dialogue." Office of the Press Secretary, January 6. www.whitehouse.gov/ the-press-office/2015/01/06/joint-statement-united-states-mexico-high-leveleconomic-dialogue

White House. 2016. United States Key Deliverables for the 2016 North American Leaders' Summit. Office of the Press Secretary, June 29. www.whitehouse.gov/ the-press-office/2016/06/29/fact-sheet-united-states-key-deliverables-2016-northamerican-leaders (accessed August 1 2016).

Wilson, Christopher E. 2011. Working Together: Economic Ties Between the United States and Mexico. Washington, DC: Woodrow Wilson International Center for Scholars. 